\title{
ローラドラフトプロセスの力学的解析
}

\author{
岥皁大学工学部 岡村政明 - 近田富士雄 - 黒崎新也
}

\section{DYNAMIC ANALYSIS OF THE ROLLER DRAFTING PROCESS}

\author{
By Masaaki Okamura, Fujio Konda and Shinya Kurosaki
}

(Faculty of Engineering, Gifu University, Kakamigahara City, Gifu Prefecture, Japan)

The roller drafting process is analysed by taking into account the following five factors: the feed sliver thickness, the delivery sliver thickness, the velocity-change-point, the drafting force and the sliver density in the drafting zone. The interactions of these factors are discussed on the basis of the preceding paper. The velocity-change-point is decided from the tuft diagrams and the sliver density in the zone with the concept of frictional force balance. The tuft diagram is calculated here from the feed sliver thickness and the delivery sliver thickness. The drafting force is deduced from the tuft diagrams, the sliver density in the zone and the velocity-change-point. On the next stage, the delivery sliver thickness is inferred from the velocity-change-point and then the sliver density in the zone from the drafting force. The roller drafting process is considered as the repetition of these four processes. The relations among the factors for the four processes are respectively derived as a function of time. The delivery sliver thickness is calculated when sliver with periodic variation is fed to the back roller. The calculated results show close agreements with experimental ones.

(Received January 29, 1981)

\section{1. 緒言}

表速が異なる二対のローラからなるローラドラフトは をれ自体単純な作用であるが，対象が一定の長さを孛っ た細い䋐維が集合したスライバであるため，そのプロセ スは非常に複雑な変動過程となる。ドラフトプロセスに ついては, 従来加ら多くの研究がみられ, 織維の配列, 織維の運動几基ついで，あるいはプロセス解析の手法 を用いで2，主に，ドラフトによって生じるむらを検討 している。しかし，それらは変速点の移動に適当な仮定 を設けて，それとむらとの関係を明らかにしているに過 ぎない。変速点はむらを左右するドラフトにおいて最す 重要なファクタであり，なぜ変速点が動くのかという問 題を解決し，それを含めた解析でなりればドラフトプロ セスを解明したとは言難い。

ところで，前報"゙れおて，変速点を浮遊繊維とロー ラに把持された䋐維の摩擦力から求め，をれとG.A.R. Fosterの理論”とから絬出スライバむらを検討した。 これはむらの発生，むらの㧕制比して，有效な知見を
与えるすのであるが，時間項を含まないため，綃出スう イバ太さの時間的変化まで吉及することはできない。し かし，その過程で用いた変速点およびG.A.R. Foster の理論は時間の関数として表わされており，これをさら に発展させ机ば，变速点の移動に関する因果関係考含め たドラフトプロセスの解析が可能になる6のと考えられ る。

本研究は前報 ${ }^{3)}$ を基礎として、ローラドラフトプロセ スを力学的に解析することを目的とした。現実のドラフ トプロセスは多くの要素が複雑に関連した変動過程であ るが，それを単純化して，要素間の相互関係を求めた。 そして，それらの関係をましめて，供給スライバの太さ 変化位対する紡出スライバ太さの時間的変化を計算し， 実測值と比較して，その妥当性を検討した。

\section{2. ローラドラフトプロセスを構成する要素}

ローラドラフトプロセスを構成する要素として，供給 スライバの断面紻維本数，紡出スライバの断面䋐維本数 执よび変速点が，まず，考えられる。一方，前報 
されたように、変速点はドラフト域のスライバ密度によ って强〈影響されるととから，てれす要菜に加える。し が，ての四つの要素だけではドラフト域のスライバ密 度は時間的に変化せず，変速点は供給スライバと紡出ス ライバの断面峨維本数だけによって決定されるととにな b。

ところで、スライバを軸方向に引張ると、スライバは その軸と直角方向比収縮する。とれはスライハ密度加軸 方向の張力によって変化するととを意味している。との 現整をローラドラフトについて考えてみる上，スライバ 軸方向の張力はドラフトカであり，そ机よってドラフ ト域のスライ滵度が変化するととになる。そてで、ド ラフト域のスライハ滵度を支配する要素としてドラフト 力を考える。前報引之同様，䄉維間の接触圧力をドラフ 惐のスライバ密度で置換えると，ドラフト力は基本的 にはフロント，バック雨ローラの把持緉維量とドラフト 搷のスライハ密度によって表現される。したがって，ド ラフトカとスライバ密度の間でループが形成され，スラ イハ密度が時間的に変化することになる。

以上のととから，ローラドラフトプロセスを構成する 要素林供給スライバの断面維維本数 $N(t)$, 紡出スライ バの断面維維本数 $n(t)$, 变速点 $S(t)$, ドラフト域の スライバ密度 $\rho(X, t)$ 㚭よびドラフト力 $D F(t)$ の五 つであるとした。

\section{3. 要素間の関係}

前述の五つの要素間の関係を検討した。ドラフトプロ 七スを構成する要素をたとえ限定したとしても，それら の姴素がそれぞれ独立ではなく，互いり複雑に影響を及ば し合っているものと考えられる。し加，その詳細を明 ら玑することは，問題をいたずらに複雑にするに過き ず，結局は，解析を不可能化する。そこで，基本となる 関係だけに注目し，要菜間の関係を图 1 の上うに考元た。 すなっち， $N(t)$ と $n(t)$ とから求的られるフロント。

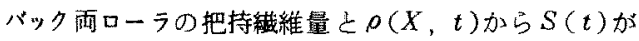

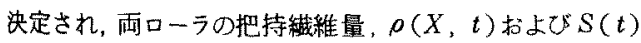
亡から $D F(t)$ が沠定される。ついで， $S(t)$ 加らn( $t)$ 加，DF(t)加ら。(X，t)加決定される。そして，乙 の四つの過程が単位となって繰返されるものとした。

つぎ，四つの過程におりる要素間の関係について検 討した。任意の時刻 $t$ 亿おけるドラフト域の状態を図 2 飞示す。ここで， $f_{1}(X, t), f_{2}(X, t)$ は時刻 $t$, 位置 Xに抽るフロント，バック両ローラの把持䋐維本数で あり， $f_{3}(X, t)$ は断面䋞維本数である。ところで， $f_{1}$, $f_{2}, f_{3}$, ○は $X$ と できれば以後の処理が简単になる。そこで，それぞれに

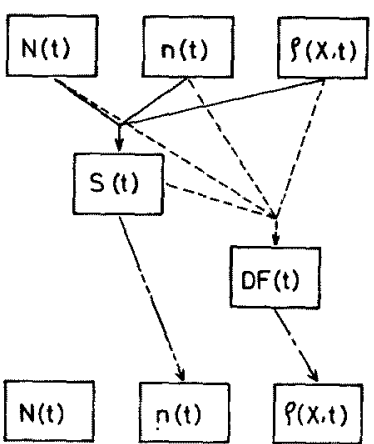

Fig. 1 Diagram showing the interactions of the following five factors.

$N(t)$ : feed sliver thickness

$n(t)$ : delivery sliver thickness

$o(X, t)$ : sliver density in the drafting zone $S(t)$ : velocity-change-point $D F(t):$ drafting force

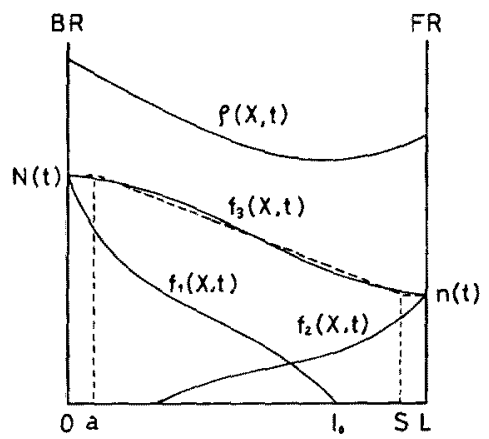

Fig. 2 Tuft diagram $f_{1}(X, t), f_{2}(X, t)$, crosssectional number of fibre $f_{3}(X, t)$ and sliver density in the drafting zone $\rho(X, t)$.

ついて，X上七の項に分離するととを考える。

(1) $f_{1}(X, t), f_{2}(X, t)$

スライバの太さにむらがある場合，その把持分布は厳 密には $X$ との関数之なる。しかし，一般には，むらの 波長は口ーラゲージよりあかなり大きく、したがって， 把持分布の時間的変化は微小であると考えてもよい。そ こで，把持分布の時間的变化は考えず，それを $f_{0}(X)$ とすると，

$$
\begin{aligned}
& f_{1}(X, t)=N(t) \cdot f_{0}(X) \\
& f_{2}(X, t)=n(t) \cdot f_{0}(X)
\end{aligned}
$$

となる。

(2) $f_{8}(X, t)$

䄳維長に対して，ローラゲージがわずかに長い場合に 
はすでに示されたように゙， $f_{\mathrm{B}}(X, t)$ を図 2 の破線の ように近似してあはとんじ問題はない。そこで， $f_{\mathrm{g}}(X, t)$ を 3 本の真線で近似し，ハックローラ側で断面緎維本数 が変化しない領域(四中のa)か時間的に一定であると仮 定すると。

$f_{8}(X, t)= \begin{cases}N(t) & 0 \leqq X \leqq a \\ \frac{(1-D) N(t)}{D\{S(t)-a}\left\{X-\frac{D \cdot S(t)-a}{D-1}\right\} & a<X \leqq S(t) \\ n(t) & S(t)<X \leqq L\end{cases}$

厄゙表わされる。

(3) $o(X, t)$

前報 ${ }^{3)}$ 乙同様， $\rho(X, t)$ をバックローラの位置で一定 䛧を羊ち、フロントローラから $15 \mathrm{~mm}$ 位置で最小値を 示す 2 次曲楾で近做し，最小做加㭙間的比変化するもの とすると，次式となる。

$\rho(X, t)=\frac{\rho_{1}-\rho_{2}(t)}{(L-15)^{2}} X^{2}-2 \cdot \frac{\rho_{1}-\rho_{2}(t)}{L-15} X+\rho_{1}$

ただし，

$$
\begin{aligned}
& \rho_{1}=\rho(0, t) \\
& \rho_{2}(t)=\rho(L-15, t)
\end{aligned}
$$

である。

つついて，図1に示された四つの過程について，要素 間の関係を検討した。

(1) $N(t), n(t)$ 战よ゙ $\rho(X, t) \longleftarrow S(t)$ の関係 前報 ${ }^{2)}$ の結果加方，長さが $l$ である浮遊繊維に対して，

$$
\begin{aligned}
& \int_{S(t)-t}^{l_{0}} \rho(X, t) \frac{f_{1}(X, t)}{f_{3}(X, t)} d X \\
& -\int_{L-l_{0}}^{S(t)} \rho(X, t) \frac{f_{2}(X, t)}{f_{3}(X, t)} d X=0
\end{aligned}
$$

となり，(1)式一(3)式を(4)式に代入すれば求める関 係老得る。

(2) $N(t), n(t), \rho(X, t)$ 占よひ $S(t)\llcorner D F(t)$ の関係

維維間の接触王力をドラフト域のスライバ密度で置換 えると，M.Hannahの理論ら)加ら次式が成立する。

$D F(t)=k \int_{L-l_{0}}^{l_{0}} \rho(X, t) \frac{f_{1}(X, t) \cdot f_{2}(X, t)}{f_{3}(X, t)} d X$

(5)式に(1)式〜(3)式を代入すれば求める関係を得 万。

(3) $D F(t)\llcorner\rho(X, t) \omega$ 関係

$\rho(X, t)$ 只(3)式で表わされることから， $\rho_{2}(t)$ 上 $D F(t)$ の関係を求めればよい。そこで, $\rho_{3}(t)\llcorner D F(t)$ を同時に測定して雨者の関倸を検討した。
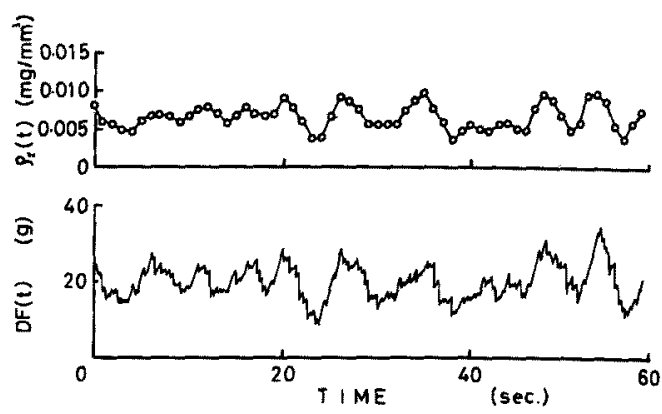

Fig. 3 Sliver density at a point in the drafting zone and drafting force.

図3は测定された結果の一例である。 $\rho_{2}(t)$ の測定は 二対の投受光器とコンデンサ型むら試験器による方法 ${ }^{2)}$ を用いておとなった。罒加ら明らかなように，雨者には 正の相関が認められる。

図 3 の結果を用いて，ドラフトカに対してスライバ密 度をプロットして，図 4 亿示す。との場合，トラフト力

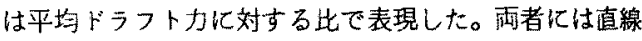
的な比例関係がみられ，相関係数を計算すると0.92であ った。ドラフト比を变化させて雨者の関係を検討した結 果，ドラフト比が小さくなると相関係数が多少小さな值 を示すが，いずれの場合にも洍線的な比例関係を示した。 したがっ

$$
\rho_{2}(t)=K_{1} \frac{D F(t)}{M D F}+K_{2}
$$

で表わされる。ことで，MDFはドラフトカの平均值で あり， $K_{1} ， K_{2}$ は比例定数である。(3)式亡(6)式とから $D F(t)$ と $\rho(X, t)$ の関係を得る。

(4) $S(t)\llcorner n(t)$ の関係

G.A.R.Foster ${ }^{1)}$ によれば，次式が成立する。

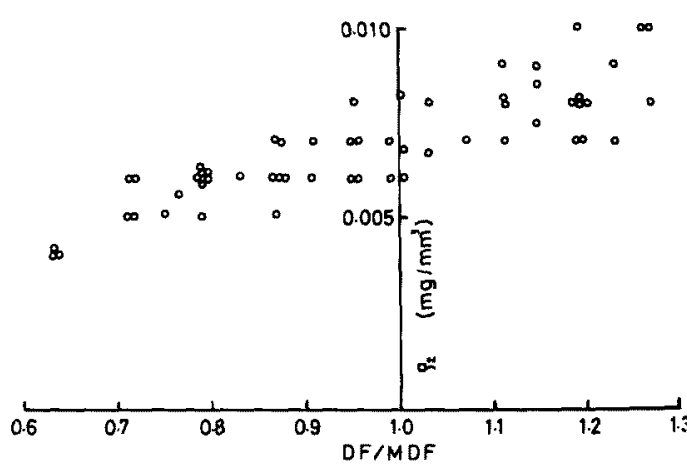

Fig. 4 Relation between drafting force/mean drafting force $(D F / M D F)$ and sliver density at a point in the drafting zone. 


$$
n(t)=\frac{V_{b}-V(t)}{V_{t}-V(t)} N(t)
$$

とてで， $V_{1}, V_{\mathrm{b}}$ はフロント，バック雨ローラの表速 でり，V(t)は变速点の移動速度である。(7)式汃ら，

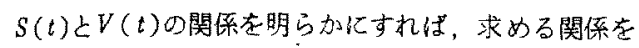
得るととができる。

速度は，一般に，移動距離とをれ亿要した時間を知れ ばその間の平均速度として求めることができる。時刻 $t_{1}$ と $t_{2}\left(t_{2}>t_{1}\right)$ で変速点か $S\left(t_{1}\right)$ 加ら $S\left(t_{2}\right)$ 人移動した とすると，

$$
V\left(t_{2}\right)=\frac{S\left(t_{2}\right)-S\left(t_{1}\right)}{t_{2}-t_{1}}
$$

となる。したがって，(7)，(8)式から $S(t)$ 上 $n(t)$ の関保老得る。

\section{4. ローラドラフトプロセス}

ドラフトが定常に達した後のローラドラフトプロセス を前節で示された関係を用いて検討した。時刻 $T_{0}$ まで 供給スライバ太さが一定であり，その後太さが变化する 場合について，图１にしたがって各要素間の関係をま之 め，図5亿示す。図の左半分は供給スライバ太さが一定 の場合であり，とこで初期条件を决定する。右半分は供 給スライバ太さが変化する場合を示し， $t \leqq T_{0}$ 㧍よむ゙ $N_{0}(t)$ はバックローラ加ら供給されたスライバがフロン トローラに達するまでに生じる時間の遅れを若虑するた めのすのである。なお，供給スライバ太さ以外の要素の 变化低対しても，一部孝変更すれば計算が可能である。

つぎ，図 5 と実際のローラドラフトプロセスとを比 較，倹討した。ポリエステル $65 \%$ ，レーヨン $35 \% ， 2 \mathrm{~d}$ ， $51 \mathrm{~mm}$ 等長に力ットされた織維加らるスライバを用 い，フロソトローラの回転を周期的倿化できるドラフ 卜装置によって，途中加ら周期むらを向つスライバを作 成した。これを供給スライバとし, 四5にしたがーて変 速点 $S(t)$ ，紡出スライバの断面縉維本数 $n(t)$ ，ドラ フトカ $D F(t) / M D F$ 拉よびスライ心密度 $\rho_{2}(t)$ 計算 した。計算に必要な定数は実験結果を参考䎲して， $L=$ $80 \mathrm{~mm}, l=51 \mathrm{~mm}, o_{1}=0.03 \mathrm{mg} / \mathrm{mm}^{3} . V_{\mathrm{f}}=26 \mathrm{~mm} / \mathrm{sec}$, $K_{1}=0.008, K_{2}=0.002, a=5 \mathrm{~mm}$ とした。な拉, 計算の 時間間隔は 5 秒 (スライバの約 $23 \mathrm{~mm}$ に相当)とした。 結果を図6に示す。图の最上が与えられた供給スライバ の断面㰄維本数 $N(t)$ の変化であり,てれを用いて計算 された他の要素の変化を以下に示した。なお，てれは $N(t)$ が変化を示し始めた時愹 $T_{0}$ を 0 秒として，それ以後 の変化の様子在示した。 $n(t), D F(t) / M D F ， \rho_{2}(t)$ は $N(t)$ に対して位相の遅れを示すが，変化の様子は同 じでる。一方, $S(t)$ は $n(t)$ 等と逆の変化を示して

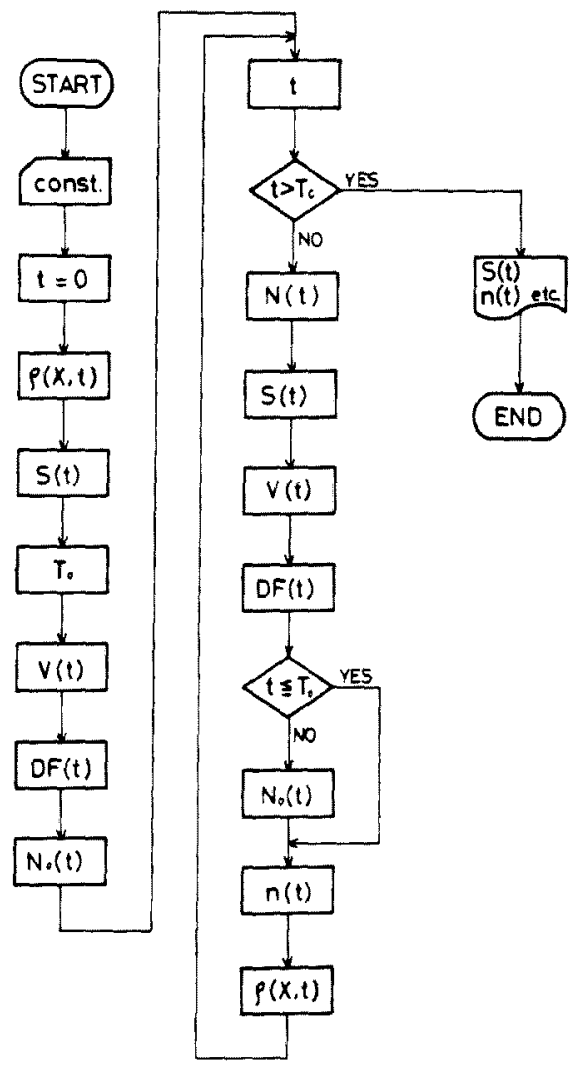

Fig. 5 Flow chart for the roller drafting process.

いるが、これはS $(t)$ がバックローラからの距離で示さ れているためであり，値の增玑はフロントローラに近つ くことを意昧している。また， $80 \mathrm{~mm} ゙$ でントローラ 一ップとなり，これ以上の增加がないために一定値が続 くことになる。

紡出スライパの断面䄉維本数 $n(t)$ につて, 実際に ドラフトして得られた結果上比較した。図6の $N(t)$ で 示された周期むらをすつフスライバをドラフト比 6 ， ロ ーラゲージ $80 \mathrm{~mm}$ でドラフトした。゙ラフトして得られ たスライバの太さを断面瀻維本数で表わし，図7亿示す。 図中の破線は図6亿示された計算に上って求められたも のである。両者を比較すると，実測值は細かな变化を示 しながら，全体として，周期的に変化しているのに対し， 計算值では細かな変化は見られず周期変化だけである。 しかし、細加な変化を除けば耐者はよい一致走し，与 えられた供給スライバの太さ変化から紡出スライバ太さ の時間的変化をとの程度まで予測できるこえが明らが なった。また，図中の細かな破線は変速点が時間的に動 かないと仮定して計算した結果である。乙の場合，䋓出 


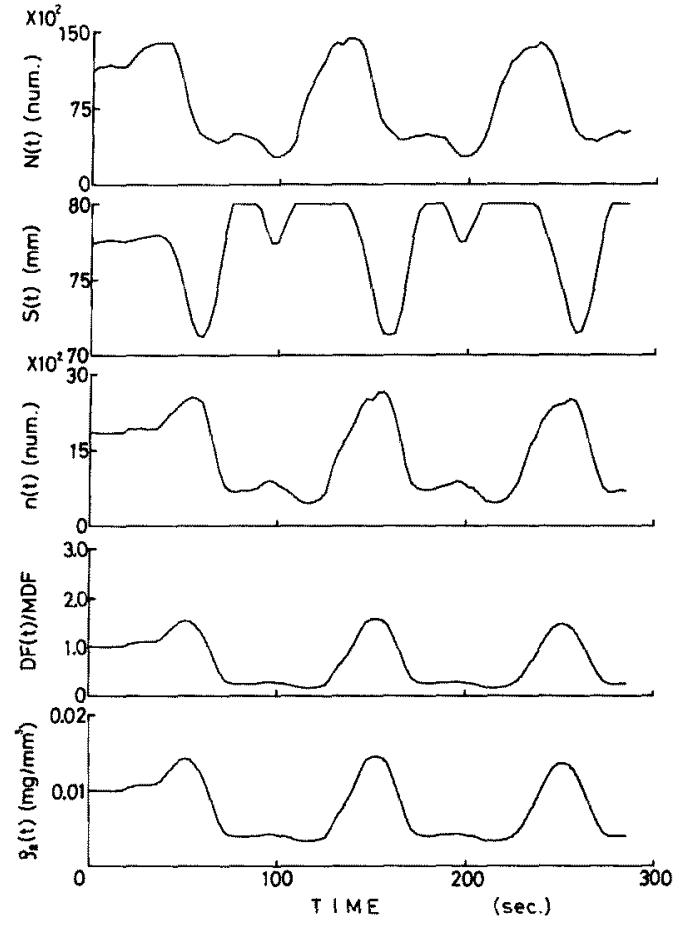

Fig. 6 Calculated results of $S(t), n(t), D F(t) / M D F$ and $\rho_{2}(t)$ for the feed sliver thickness variation. $(D=6, R G=80 \mathrm{~mm})$

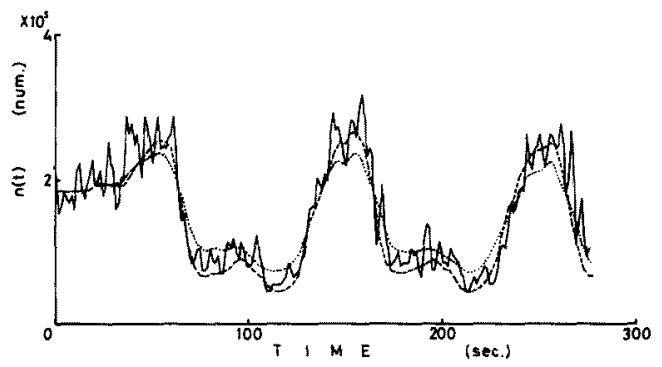

Fig. 7 Delivery sliver thickness.

$$
\begin{aligned}
& \text { _ experimented } \\
& \text { - - calculated } \\
& \text {-..- calculated }(S(t)=\text { const. })
\end{aligned}
$$

スライバ太さは供給スライバ太さが単にドラフト比分の 1 になったあのであり，前二者之比較すると，太い部分 はそれらよりも細く，細い部分は逆比太くなっている。 したがって，変速点が動かない場合には，紡出スライバ のむらは少なく表現され，従来加言われているように， 変速点の変動がむらに大きく影響しているととがかかる。 図 8 は図 7 と同じ波長をむち，振幅が異なる試料につ

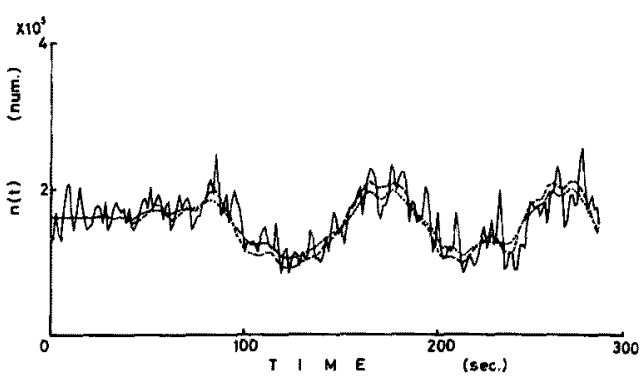

Fig. 8 Delivery sliver thickness.

- experimented

- - calculated

-.- calculated $(S(t)=$ const. $)$

いての結果である。この場合にも，実測值に見われる細 加な変化を除けば、両者はよく一致している。

以上のように，本研究で示された結果は現䒠を十分に 説明でき，ローラドラフトプロセスの検討に対して極め て有効であると考えられる。

\section{5. 結言}

前報で得られた知見をもとにして、ローラドラフトプ 口セスを力学的に解析した。結果をまとめると，つぎの ようになる。

（1）ローラドラフトプロせスを構成する要素は供給ス ライバの断面䋐維本数，紡出スライバの断面䋐維本数， 変速点，ドラフト力およびドラフト域のスライバ密度の 五つであるとした。

（2）ローラドラフトプロセスは図1に示された四つの 過程の繰返しであると考え，それぞれの過程机いて， 要素間の関係を明ら加にした。

（3）周期むらをあつスライバをドラフトした場合，計 算によって求めた紀出スライバ太さの時間的変化は実際 にドラフトして得られたそれとよく一致し，本研究で示 されたローラドラフトプロセスの解析の罗当性が確かめ られた。

\section{文献}

1）たとえば, G.A.R.Foster； J.Text. Inst., 42, T 336 (1951)

2）たとえば，藤野，川端；瀻機誌，14，630(1961)

3）岡村, 近田, 黑崎; 織学誌，36，T240 (1980)

4）岡村, 近田, 黒崎, 脇田, 丹羽; 岐阜大工研報, 27, 30 (1977)

5) M. Hannah; J. Text. Inst., 41, T57 (1950)

6) S. Kurosaki, F. Konda, M. Okamura; Int. Wool Text. Res. Conf., IV-16 (1975) 